\title{
Comparison of Bacterial Colonization and the Biofilm Formation between Indwelling Pure Silicone and Silicone Coated Latex Catheters: A Prospective and Observational Study
}

\author{
Sudish Kumar ${ }^{1}$, Abhishek Bose ${ }^{2}$ \\ ${ }^{1}$ Associate Professor, Department of Surgery, ${ }^{2}$ Assistant Professor, Department of Urology, Narayan Medical \\ College and Hospital, Sasaram
}

\begin{abstract}
Introduction: $30 \%-40 \%$ of all the hospital acquired infections are due to Catheter Associated Urinary Tract Infections (CAUTIs), is directly associated with increase in morbidity, mortality, hospital costs and length of the hospital stay. In acute care setting, the prevalence of CAUTIs in the catheterized patient increases with increase in days of catheterization. Bacterial species isolated in CAUTIs show biofilm production, which provides survival benefit to them by providing protection from environmental stresses and causing decreased susceptibility to antimicrobial agents. This study was designed and conducted to compare bacterial colonization, isolation of bacteria and biofilm production property in patients who were catheterized with two most common indwelling catheter; pure silicone and silicone coated latex catheters.
\end{abstract}

Materials and Method: This prospective, observational and comparative study was conducted on 200 patients of all age and gender who had been catheterized for more than 7 days and had sterile precatheterisation urine. Divided into Group A (pure silicone catheter) and B (silicone coated latex catheter) with 100 patients each. Urine culture was done on the $8^{\text {th }}$ day of indwelling urinary catheter drainage. If growth was detected, then that bacterium was tested for biofilm production property by tissue culture plate method. Results were analysed with the help of Instat Graph Pad software.

Results: Bacterial colonization and uropathogens showing Biofilm forming bacteria was more seen in group B patients with respect to group A patients and the difference was significant. In both the groups the most common bacteria were Escherichia coli.

Conclusion: Pure silicone catheter was advantageous over the most commonly used silicone coated latex catheter in terms of bacterial colonization and biofilm formation, although pure silicone catheter didn't completely resist the bacterial colonization and the biofilm formation. Keywords: Catheter Associated Urinary Tract Infections, Pure silicone catheter, Silicone coated latex catheter

\section{Introduction}

In hospitals and nursing homes Catheter Associated Urinary Tract Infections (CAUTIs) are the most

\section{Corresponding author:}

\section{Dr. Abhishek Bose}

Assistant Professor, Department of Urology, Narayan Medical College and Hospital, Sasaram Email ID- abhishek130@yahoo.com, Mobile Number9430251398 common nosocomial infections and constitutes about $30 \%-40 \%$ of all the hospital acquired infections. ${ }^{[1-4]} 70$ $80 \%$ of CAUTIs are due to use of an indwelling urethral catheter. ${ }^{[5]}$

Increase in morbidity, mortality, hospital costs, and length of the hospital stay is directly associated with CAUTIs. Almost every healthcare-associated UrinaryTract Infections (UTIs) occurs due to instrumentation of the urinary tract i.e. insertion of catheters and Female sex, older age, prolonged catheterization, impaired 
immunity, diabetes, renal dysfunction, severity of illness, insertion of the catheter outside of the operating room, inadequate professional training of the person who inserts the catheter, incontinence and the inpatients in the orthopaedic and the neurology departments are the risk factors for CAUTIs. ${ }^{[6]}$

In acute care setting, the prevalence of CAUTIs in the catheterized patient is 3\%-7\% (when urinary catheter is used for $<7$ days), $25 \%$ (when urinary catheter is used for $>7$ days) and becomes $100 \%$ (when urinary catheter is used for $>30$ days). ${ }^{[7-9]}$

The sources of the microorganisms which cause CAUTIs can be ${ }^{[10]}$

Endogenous, i.e., via meatal, rectal or vaginal colonization or

Exogenous, i.e., via the contaminated hands of the healthcare personnel or via contaminated equipment.

Microbial pathogens can enter the urinary tract either by the ${ }^{[10]}$ extra-luminal route along the outside of the catheter, or intra-luminal route along the internal lumen of the catheter from the contaminated collection bag or from the catheter drainage tube junction.

Bacteria starts to form a biofilm as the duration of the catheterization increases and this biofilm provides resistance against antimicrobials and the infection becomes difficult to treat. ${ }^{[11]}$

CAUTIs comprise one of the largest institutional reservoirs of nosocomial pathogens ${ }^{[12-14]}$ and the most common pathogens are multidrug-resistant Enterobacteriacae, other than Escherichia coli, such as Klebsiella, Enterobacter, Proteus, and Citrobacter; Pseudomonas aeruginosa; A. baummannii; Enterococci and Staphylococci and Candida spp. ${ }^{[15]}$

Urinary-Tract Infections (UTIs) are defined by using Symptomatic Urinary Tract Infection (SUTI) criteria or Asymptomatic Bacteraemic UTI (ABUTI) criteria. UTIs that are catheter-associated (i.e., in which the patients have an indwelling urinary catheter at the time of or within 48 hours before the onset of the event) are reported by using diagnostic criteria as per the CDC guidelines. ${ }^{[16]}$ Approximately $17 \%$ of Bacteraemias are from urinary sources with mortality rate of around $10 \%$. [17]
Many bacterial species produce a biofilm mode of growth for their survival. ${ }^{[18]}$ The most common organisms which commonly contaminate urinary catheter and develop biofilms are biofilm forming strains of Escherichia coli, Pseudomonas aeruginosa, Enterococcus, Proteus mirabilis and Klebsiella pneumonia. ${ }^{[19]}$

These strains carry an array of adhesins in their walls and on contact with a surface; they secrete exopolysaccharides that promote their attachment. These bacteria then multiply and spread over the surface, forming colonies embedded in a gel-like polysaccharide matrix. ${ }^{[18]}$

The bacteria in these biofilms lead to the persistence of microorganisms by providing protection for them from environmental stresses and it also leads to decreased susceptibility to antimicrobial agents. ${ }^{[20]}$

For the manufacture of Foley catheter first material used was latex. Latex has problems like relatively poor biocompatibility and a susceptibility to infection and encrustation. ${ }^{[21]}$ to resolve these problems different type of coatings was applied to the surface of latex including the biocidal coatings such as silver coating; polymeric ones such as based on poly (2-hydroxyethyl methacrylate) (PHEMA), Polytetraflouroethylene (PTFE) and silicone. ${ }^{[22]}$ Silicone which is considered one of the most biocompatible substances is also used in the manufacture of pure silicone catheter, made entirely of silicone. ${ }^{[21]}$ The advantage of pure silicone catheter for long term catheterization is well established. ${ }^{[23]}$

Silicone coated latex catheter and Pure silicone catheter are the two most common types of catheters used in our hospital. This study was designed and conducted to compare bacterial colonization, isolation of bacteria and biofilm production property in patients with indwelling pure silicone and silicone coated latex catheters.

\section{Materials and methods}

Study site-This study was conducted in the Department of General Surgery, Narayan Medical

College and Hospital, Jamuhar, Bihar, India.

Study duration - One year from January 2018 to December 2018

Study design- Observational, prospective and 
comparative study. 200 patients were selected from indoor of the Department of General Surgery. Patients were divided into 2 groups on the basis of type of indwelling catheter utilized. Group A $(n=100)$ patients were on pure silicone catheter and Group B $(n=100)$ patients were on silicone coated latex catheter. Study was approved from Institutional Ethics Committee of $\mathrm{NMCH}$, Jamuhar. Informed consent was taken from each study participants.

\section{Inclusion criteria}

Patients of all age group and all gender.

Patients who has needed indwelling urinary catheterization for more than 7 days.

Patients with sterile urine before catheterization were included. For this midstream urine was sent for culture under all aseptic conditions.

\section{Exclusion criteria}

Patients with urinary tract infection or bacterial growth on precatheterisation urine culture.

Patients who has to be catheterized for less than 7 days.

Immunocompromised patients.

Patients with indwelling catheters inserted from other hospital and shifted to our hospital for further management.

Patients who are not fitting WHO/CDC/NHSN definition of CAUTI. ${ }^{[24-27]}$

16 French pure silicone catheters were inserted in Group A ( $\mathrm{n}=100)$ patients and 16 French silicone coated latex catheters were inserted in Group B $(n=100)$ patients after fulfilling the inclusion criteria of our study. Closed catheter drainage was maintained and the catheter was positioned well secured to prevent any traction with urine collection bag always kept below the level of urinary bladder. Proper perineal hygiene was maintained.

On the $8^{\text {th }}$ day, indwelling catheter was drained and urine sample was taken aseptically with the help of sterile syringe and needle. Catheter drainage tubing was clamped to allow collection of freshly voided urine. After cleaning catheter port with 1\% Povidone iodine, a 21-gauze needle attached to the syringe was inserted in the catheter port between junction of drainage tubing and tubing from the balloon. Urine was aspirated into the syringe for culture.

Urine sample was sent to Department of Microbiology, $\mathrm{NMCH}$, Jamuhar for routine standard laboratory procedure like microscopy and culture identification. Microscopy was performed on centrifuged catheter urine sample. Cultured was done on Cysteine Lactose Electrolyte Deficient Agar for isolation of all types of urinary pathogens. Blood agar and MacConkey agar was used in few cases. Isolate suggestive of yeast were cultured on Sabouraud's Dextrose Agar. Culture plates were incubated aerobically at $37^{\circ} \mathrm{C}$ for $18-24$ hours. ${ }^{[28]}$ Identification of the microorganism was done by colony morphology, gram's staining and biochemical reactions.

Biofilm formation property was tested by Tissue Culture Plate Method (gold-standard method for biofilm detection) if growth was detected. ${ }^{[29]}$

Organisms isolated from culture plates were inoculated in $10 \mathrm{ml}$ of trypticase soy broth with $1 \%$ glucose and were incubated at $37^{\circ} \mathrm{C}$ for 24 hours. Free floating bacteria were removed by gentle tapping and washing with $0.2 \mathrm{ml}$ of phosphate buffer saline (pH 7.2) four times. Adherent biofilm was detected by fixing with $2 \%$ sodium acetate and staining with $0.1 \%$ crystal violet. [30]

Statistical analysis: Data collected from this study was analysed using statistical software Instat GraphPad. The students t-test was used to compare both the groups and the $p$-value $\leq 0.05$ was considered significant.

\section{Results}

Table 1: Difference of Bacterial Colonization and Uropathogens after 7 days of indwelling catheter in both groups

\begin{tabular}{|l|l|l|l|}
\hline & $\begin{array}{l}\text { Group } \\
\text { A (Pure } \\
\text { Silicone } \\
\text { catheter, } \\
\text { indwelling catheter } \\
\text { (Number of patients) }\end{array}$ & $\begin{array}{l}\text { Group B } \\
\text { (Silicone } \\
\text { coated latex } \\
\text { catheter, } \\
\mathbf{n}=\mathbf{1 0 0 )}\end{array}$ & $\begin{array}{l}\mathbf{p} \\
\text { value }\end{array}$ \\
\hline $\begin{array}{l}\text { No Bacterial } \\
\text { Colonization }\end{array}$ & 76 & 56 & $<0.05$ \\
\hline Bacterial Colonization & 24 & 44 & $<0.05$ \\
\hline $\begin{array}{l}\text { Uropathogens showing } \\
\text { Biofilm formation }\end{array}$ & 8 & 32 & $<0.05$ \\
\hline
\end{tabular}


Bacterial Colonization was more in isolates from group B patients and the difference was significant with respect to isolates from group A patients. Uropathogens showing Biofilm forming bacteria was more seen in patients with indwelling silicone coated latex catheter $(\mathrm{n}=32)$ with comparison to patients with indwelling pure silicone catheter $(\mathrm{n}=8)$ and the difference was significant.

Table 2: Species of bacterial colonization in both groups

\begin{tabular}{|c|c|c|c|c|c|}
\hline \multicolumn{2}{|c|}{$\begin{array}{l}\text { After } 7 \text { days of indwelling catheter } \\
\text { (Number of patients) }\end{array}$} & $\begin{array}{l}\text { Group A (Pure Silicone } \\
\text { catheter, } n=100 \text { ) }\end{array}$ & $\%$ & $\begin{array}{l}\text { Group B (Silicone coated } \\
\text { latex catheter, } n=100 \text { ) }\end{array}$ & $\%$ \\
\hline \multicolumn{2}{|c|}{ Bacterial colonization } & 24 & & 44 & \\
\hline \multicolumn{2}{|c|}{ Multiple organisms isolated } & 6 & & 8 & \\
\hline \multicolumn{2}{|l|}{ Total } & 30 & & 52 & \\
\hline \multirow{6}{*}{$\begin{array}{l}\text { Bacteria } \\
\text { Isolated }\end{array}$} & E. coli & 10 & 33.33 & 18 & 34.62 \\
\hline & Pseudomonas & 8 & 26.67 & 16 & 30.77 \\
\hline & Enterobacter & 8 & 26.67 & 14 & 26.92 \\
\hline & Proteus & 2 & 6.67 & 2 & 3.85 \\
\hline & Citrobacter & 2 & 6.67 & 0 & 0.0 \\
\hline & Klebsiella & 0 & 0.0 & 2 & 3.85 \\
\hline
\end{tabular}

This table shows that difference on the basis of individual bacterial isolate in both the groups was not significant. E. coli $(33.33 \%$ in group $\mathrm{A}, 34.62 \%$ in group B i.e. most common organism in both the groups) then Pseudomonas $26.67 \%$ in group A and $30.77 \%$ in group B), Enterobacter (26.67\% in group A and 26.92\% in group B), Proteus (6.67\% in group A and $3.85 \%$ in group B) were the bacterial isolate found in this study. Citrobacter $(6.67 \%)$ was found only in group A and Klebsiella (3.85\%) was found only in group B.

This study showed that patients with indwelling silicone coated latex catheter for 7 days had significantly more bacterial colonization and biofilm production than patients with indwelling pure silicone catheter for 7 days.

\section{Discussion}

Urethral catheter is one of the major underlying factors in causation of nosocomial urinary tract infections. About $15-25 \%$ of all hospitalized patients require catheterization ${ }^{[4]}$ and nosocomial urinary tract infections may progress to gram negative septicaemia in $30-40 \%$ of patients. ${ }^{[31]}$ Biofilms provides protection to the uropathogens from environmental stresses and also leads to decreased susceptibility of the colonizing bacteria to the antimicrobial agents. ${ }^{[32]}$

Silicone coated latex and pure silicone catheters are the two commonly used urinary catheters in our hospital. The silicone coating on the latex improves the biocompatibility of the catheter and decreases the tissue inflammation. Pure silicone is favored for urethral catheter due to its mechanical strength, elasticity, greater rigidity, relatively thin wall which creates a larger drainage lumen and takes longer time to encrust and block ${ }^{[21,33]}$ but it is more expensive and causes more discomfort to the patients due to rigidity. ${ }^{[34,35]}$

Sabbuba et al., had showed the superiority of pure silicone catheter similar to our study. ${ }^{[36]}$ Gabriel et al., showed that there was no advantage of pure silicone catheter in terms of bacterial colonization. ${ }^{[37]}$ Morris et al., showed that pure silicone catheter was not advantageous in resisting bacterial colonization and the biofilm formation. ${ }^{[35]}$ Kumon et al., showed that silicone is superior in terms of bacterial colonization and biofilm formation. ${ }^{[38]}$ 
Reason for superiority of pure silicone catheter was given by Lawrence et al. He concluded that the surfaces of pure silicone catheter are smoother and shows little change over time but the silicone coated latex catheter shows peeling from the underlying latex substrate possibly because of a mismatch in moduli between coating and substrate. ${ }^{[39]}$

Prevention of CAUTI in patients with indwelling urinary catheter is a big challenge. In past many decades various attempts have been made to decrease the occurrence of CAUTI by introduction of various catheter coatings and new constituent catheter material.

\section{Conclusion}

Pure silicone catheter was advantageous over the most commonly used silicone coated latex catheter in terms of bacterial colonization and biofilm formation, although pure silicone catheter didn't completely resist the bacterial colonization and the biofilm formation.

\section{Source of Funding: Self}

\section{Conflict of Interest: None}

Ethical Clearance: Taken

\section{References}

1. National Center for Health Statistics, Centers for Disease Control and Prevention, U.S. Dept. of Health and Human Services, September 2004. 13(157). Hyattsville, MD.

2. Zarb P, Coignard B, Griskevicienne J, Muller A, Vankerckho ven Weist K, Goossens MM, Vaerenberg S, Hopkins S, Catry B, Monnet DL, Goosens H, Suetens C: The European Centre for Disease Prevention and Control (ECDC) pilot point prevalence survey of healthcare-associated infections and antimicrobial use. Euro Surveill 2012, 17(46):pil=20316.

3. Magill SS, Edwards JR, Bamberg W, Beldaus ZG, Dumyati G, Kainer MA, Lynfield R, Maloney M, McAllister-Hollod L, Nadle J, Ray SM, Thompson D, Wilson LE, Fridkin SK: Multistate point-prevalence survey of health care-associated infections. N Engl J Med 2014, 370:1198-1208.

4. Iacovelli V, Gaziev G, Topazio L, Bove P, Vespasiani G, Finazzi AE. Nosocomial urinary tract infections: A review. Urologia. 2014;81(4):222-27.

5. A Nicolle: Catheter associated urinary tract infections. Antimicrobial Resistance and Infection Control 2014 3:23. doi:10.1186/2047-2994-3-23.

6. Gould CV, Umscheid CA, Aggarwal RK, Kuntz G, Pegues DA. Healthcare Infection Control Practices Advisory Committee. Guideline for prevention of catheter-associated urinary tract Infections 2009.

7. Lo E, Nicolle L, Classen D, et al. Strategies to prevent catheter associated urinary tract infections in acute care hospitals. Infection Cont and Hosp Epid. 2008; 29 (1): s41-50.

8. Centers for Disease Control and Prevention (CDC). Emerging Infectious Diseases Posted; Emerging Infectious Diseases. 2001;7(2) (C) 2001.

9. Saint S, Lipsky BA, Goold SD. Indwelling urinary catheters: a one-point restraint? Annals of Internal Medicine. 2002;137(2):125.

10. Tambyah PA, Halvorson KT, Maki DG. A prospective study on the pathogenesis of catheterassosiated urinary tract infections. Mayo Clin Proc. 1999; 74(2): 131-36.

11. Saint S, Chenoweth CE. Biofilms and catheterassociated urinary tract infections. Infect Dis Clin North Am. 2003;17(2):411-32.

12. Stark RP, Maki DG. Bacteriuria in the catheterized patient. N Engl J Med 1984;311:560-64.

13. MakiDG. Nosocomial bacteremia. An epidemiologic overview. Am J Med 1981;70:719-32.

14. Krieger JN, Kaiser DIL, Wenzel RP. The urinary tract etiology of the bloodstream infections in hospitalized patients. J Infect Dis 1983;148:57-62.

15. Maki* Dennis G. and Tambyah† Paul A. Engineering Out the Risk for Infection with Urinary Catheters Em Infect Dis March-April 2001; 7 ( 2): 342-47.

16. h t t p : / / w w w . c d c . g o v / n h s n/p d f s / pscManual/7pscCAUTIcurrent.pdf (Accessed on 4 March 2009).

17. Weinstein MP, Towns ML, Quarterly SM, et al. Clinical significance of positive blood cultures in the 1990s: A prospective comprehension evaluation of the microbiology, epidemiology and the outcome of the bacteremia and fungemia in adults. Clin Infect Dis. 1997; 24(4):584-602.

18. Subramanian P, Shanmugam N, Sivaraman U, Kumar S, Selvaraj S. Antiobiotic resistance pattern of biofilm forming uropathogens isolated from catheterized patients in Pondicherry, India. Australas Med J. 2012;5(7):344-48. 
19. Stickler DJ. Clinical complications of urinary catheters caused by crystalline biofilms: something needs to be done. J Intern Med. 2014;276(2):12029.

20. Mittal S, Sharma M, Chaudhary U. Biofilm and multidrug resistance in uropathogenic Escherichia coli. Pathog Glob Health. 2015;109(1):26-29.

21. Lawrence EL, Turner IG. Materials for urinary catheters: a review of their history and development in the UK. Med Eng Phys. 2005;27(6):443-53.

22. Liu H, Wang Q, Wei L, Yu H. Surface modification of natural rubber latex films by hydroxyethyl methacrylate. Polymer Science Ser B. 2015;57(6):623-30.

23. Carton L. Aseptic Techniques. In: Adler AM, Carlton RR, editors. Introduction to Radiologic and Imaging Sciences and Patient Care. 6th ed. Canada: Saunders Elsevier; 2016. pp.238.

24. https://www.who.int/infection-prevention/tools/ core-components/CAUTI_student-handbook.pdf.

25. https://www.cdc.gov/infectioncontrol/pdf/ guidelines/cauti-guidelines-H.pdf.

26. ht t p s : // w w w . cd c.gov/n h s n/ P D F s/ pscManual/7pscCAUTIcurrent.pdf.

27. https://healthinsight.org/Internal/assets/Hospital/ Resources/NHSN_CAUTI_12_16_11.pdf.

28. Hilt EE, McKinley K, Pearce MM, Rosenfeld AB, Zilliox MJ, Mueller ER, et al. Urine is not sterile: use of enhanced urine culture techniques to detect resident bacterial flora in the adult female bladder. $\mathrm{J}$ Clin Microbiol. 2014;52(3):871-76.

29. Mathur T, Singhal S, Khan S, Upadhyay DJ, Fatma T, Rattan A. Detection of biofilm formation among the clinical isolates of staphylococci: an evaluation of three different screening methods. Indian J Med Microbiol. 2006;24(1):25-29.

30. Hassan A, Usman J, Kaleem F, Omair M, Khalid A, Iqbal M. Evaluation of different detection methods of biofilm formation in the clinical isolates. Braz $\mathrm{J}$ Infect Dis. 2011;15(4):305-11.

31. Manish N, Tankhiwale NS. Study of microbial flora in patients with indwelling catheter. Int J Cur Res Rev. 2013;05(12):57-60.

32. Soto SM, Smithson A, Martinez JA, Horcajada JP, Mensa J, Vila J. Biofilm formation in uropathogenic Escherichia coli strains: relationship with prostatitis, urovirulence factors and antimicrobial resistance. J Urol. 2007;177(1):365-68.

33. Morris NS, Stickler DJ, Winters C. Which indwelling urethral catheters resist encrustation by Proteus mirabilis biofilms? Br J Urol. 1997;80:58-63.

34. Denstedt JD, Wollin TA, Reid G. Biomaterials used in urology: current issues of biocompatibility, infection, and encrustation. $\mathrm{J}$ Endourol. 1998;12(6):493-500.

35. Hamill TM, Gilmore BF, Jones DS, Gorman SP. Strategies for the development of the urinary catheter. Expert Rev Med Devices. 2007;4(2):21525.

36. Sabbuba N, Hughes G, Stickler DJ. The migration of Proteus mirabilis and other urinary tract pathogens over Foley catheters. BJU International. 2002;89:55-60.

37. Gabriel MM, Mayo MS, May LL, Simmons RB, Ahearn DG. In vitro evaluation of the efficacy of a silver-coated catheter. Curr Microbiol. 1996;33(1):01-05.

38. Kumon H, Hashimoto H, Nishimura M, Monden K, Ono N. Catheter-associated urinary tract infections: impact of catheter materials on their management. Int J Antimicrobiol Agents. 2001;17:311-16.

39. Lawrence EL, Turner IG. Characterisation of the internal and external surfaces of four types of Foley catheter using SEM and profilometry. J Mater Sci Mater Med. 2006;17(12):1421-31. 